\title{
An Overview of Push/Pull Factors of Political Participation in Nigeria
}

\author{
${ }^{1}$ Muhammad Fuad Othman, ${ }^{2}$ Nazariah Osman \& ${ }^{3}$ Isah Shehu Mohammed \\ ${ }^{1}$ \& 2 School of International Studies, Universiti Utara Malaysia, Malaysia \\ ${ }^{3}$ General Studies Department, Federal Polytechnic, Bauchi-Nigeria \\ ${ }^{1}$ Corresponding author: mfuad@uum.edu.my \\ DOI: https://doi.org/10.32890/jis2018.14.6
}

Received: 3 January 2018

Revised: 8 April 2018

Accepted: 10 June 2018

\begin{abstract}
This article overviews the push/pull factors of citizens' participation in Nigerian politics. Citizens' participation in state politics is both integral and an indispensable part of every political system and development. However, it is determined by numerous factors which are universal, but relative in terms of contexts. Such a participation is affected by many factors in Nigeria. The study uses secondary sources to collect data and perform qualitative analysis. The study is timely and significant in view of the critical roles where participation plays in shaping and influencing Nigerian politics, especially at the current moment when it is being characterized by apathy and participation on two ends. It is concentrated on an atmosphere of push and pull forces, negative and positive issues and developments, this environment is manipulated by elites/politicians. This needs a change for the better, to inculcate hope, overcome despair, anxiety as well as increased ethno-religious and electoral tensions.
\end{abstract}

Keywords: Nigeria, Participation, Politics, Pull/Push Factors.

\section{Introduction}

Human beings are political animals whose lives are significantly determined and influenced by politics. Although the extent to which politics influence and determine the relations is relative to situations such as personality involved; and socio-economic and environmental factors, endeavours of life are dependent on political decisions; and political participation and or apathy affect everything and result in many things - standard/cost of living, freedom, equality and rights, justice, state of health, education, family structure, success or failure of a state system, international relations. Politics in relations is basically aimed at achieving some objectives, which are ideally good. The more human beings become exposed and related to others, the more politics influences and determines their lives and interactions. Politics amongst humanbeings is practiced and observed at both the private - personal relations with friends, enemies, family, groups and communal members; and at the public/states levels of activities - political parties, direct/indirect, voluntary/involuntary, negative/positive, 
peaceful/violent involvement in public affairs. As states evolve over time, environment and space, the political relations of the humanbeings also develop, systematise, and become general, inclusive and complex. These are, however, dependent on several factors environment, economy, security, and heterogeneous/homogeneous composition of the state/ society which gradually develop into the art and science of politics (Kahne \& Westheimer, 2006). Political participation, is therefore, the bedrock on which political activities in any state/society are carried out. The success or failure is also determined by the size, quality and ideality of the participants who are the citizens. Therefore, social actions are dependent upon relations among individuals and political participation is dependent upon the flow of relations among the citizens, the state and the society. As such political issues and trends are a creative response to structural circumstances of a political environment inhabited by people (Preston, 1997:1). In this modern era, political participation has become the main means through which citizens participate, determine, influence and create impact on their states' affairs with the citizens and their states' authorities.

Relations amongst Nigerians, between them and the Nigerian state, are similarly influenced and affected by politics, as well as, the extent to which citizens participate in it. This article over-views the push/pull factors of political participation in Nigeria. It is a state that comprises of the most heterogeneous and complex political compositions, character and dimensions of political background, set-up and practices.

\section{Problem Statement}

There is an alarming decrease in public participation in poliics, particularly in the traditional political participation and amongst the youth. This results in political fluctuation, along with the decline of clean and honest politics, and politicians, especially in Nigeria, (Skoric \& Poor, 2013; Thun, 2014; Harris, Wyn \& Younes, 2010; Curran, Fenton \& Freedman, 2012). Consequently, a large number of Nigerian citizens have little or no confidence in both the politicians and the state. Therefore, they participate less or with little interest in Nigerian politics; political activities and relations in Nigeria as it is more associated with violence, thuggery and other nefarious acts in the society, and due to this, many abhor the politics and do not want to be associated with it; citizens are thus pushed out of participation in the politics (Flores \& Nooruddin, 2016:144). Most Nigerians misperceive political participation and thus only see and reduce it to franchise exercise (voting during elections). However, there are desperations, appropriate and strong determination to not only participate, but also cause and effect changes in the polity due to some other factors which pull Nigerians to participate. Although those may not necessarily be for the good of either the individual or the public, citizens still show interest and participate in the politics.

The Nigerian political environment is on one hand synonymous with violence, risks, deceptions, money spills, untrustworthiness and other generally negative impressions. Likewise, participation in the politics is also associated with high risk taking, extreme disappointments, and malpractice, and prone to violence such as (orchestration of conflicts 
and violence, character and personality assassinations, arson, thuggery, ballot boxes snatching, entrepreneurship in ethnicity and conflicts). The political process has become substantially monetised by many of the state authorities, politicians, the parties and individual citizens (Amadi, 1982:89; Jacob \& Abdullahi, 2007). Simultaneously, issues of ethnicity, religion, rivalry, sectional and regional proclivities are pulling Nigerians towards participating in the politics in order to guard their particularistic interests, which are subjected to the manipulation of the elites and politicians. There are other Nigerians who summon the courage to participate with the desire to cause and effect changes and for the betterment of the Nigerian state and her citizens.

\section{Methodology}

This study is premised upon Nigerians' participation in politics with an overview of the push and pull factors of the participation. The study used the qualitative method as collection and analysis of the data which were obtained from secondary sources. Qualitative collection and analysis of data enables a study to digest issues from a flexible multi-dimensioned approaches using the qualitative techniques of research paradigm. The current practical situation, various scholars and politicians, and prevailing socio-economic and ethnoreligious conditions and circumstances were examined and qualitatively analysed in line with the push/pull factors identified by the study. This research was conducted at the time when Nigeria was experiencing consistent rise and decline of political participation based on the identified factors in this research.

\section{Politics and Political Participation}

The citizens' participation in politics and political system of a state is essential and not new in the history of states. This (directly or indirectly) shapes the evolution and forms the bedrock of consolidating the state, sound public institutions and good governance on issues relating to security, welfare, health, among others which had prompted gatherings and action taking amongst peoples (McManimon, 2014). However, political participation as it is today, evolves and develops in both gradual and pragmatic manner; over time, space and environment uniqueness; and evolution of states (Gromping, 2014; Suhana \& Ali, 2012). This standpoint has resulted in political participation shapes, guides, and influences the making and re-making of public policies and implementation, as well as the efficacy of public leadership in order to achieve accountable and transparent leadership, particularly in settings where citizens have the equal rights to political participation (Education, Audio-Visual and Culture Executive Agency [EACEA], 2013; Mayoral, 2011). This makes participation very essential to the politics, democracy and good governance (Bakker \& Vreese, 2011). Poor or non-participation/apathy resulted in many damages not only to the state but also to the citizens, in a variety of angles which range from criminality, broken homes, corruption, dictatorship, political upheaval of a state, and other damaging consequences to the society and state. 
Hence, participation is not only important but also affects and determines the performance of the government, secures legitimacy for the state authorities and consequently affects the public and private lives of the citizens (Stolle \& Hooghe, 2011). Generally, whether individuals participate or not and their extent of participation is dependent and determined by several factors, including the normative model of political system or the type of democracy that is invoked by a state. There are a variety of determinants for political participation which may be for either personal or public gains,deriving pleasure in the participation, social influence especially with the advancement of social media, which further enhances the traditional political participation.

\section{Conceptualisation and Review}

Political participation is popular and widely studied among politicians, states and academics/ scholars. Therefore, it has resulted in rich literature. However, contexts and conscriptions of participation vary from one environment, political system, and economy, cultural and ethno-religious drive to another. There is, however, a general contextualisation on which it is generally approached and conceptualised, leaving the in-depth conscriptions to the individual units/states of analysis. Bakker and Vreese (2011) state that political participation is an instrument for democratic commitment through membership, voting in elections, and acquiring political knowledge and education. For Waller (2013), political participation comprises of activities of interaction with politicians, participating in civic groups and organisations, and engagements in political activities such as petitions, campaigns, demonstrations and debates.

Similarly, Thun (2014) described participation as the on and off line political activities (political information dissemination, discussions, exercising voting rights, political interactions, among others), while Chan (2015) depicted it as activities of the citizens' which have bearings on the policies and actions of governments. He also identified the conventional 'political participation' which stated that it is the citizens' responsibility and active involvement to carry out political activities such as campaigns, volunteership and elections. The 'unconventional participation' which involves other political actions that may be considered insubordinate, immoral or illegal (writing/signing complaints, and petitions,), but these have effects on the political system. Thus, many other acts which have a connection to politics are also included as a part of political participation. Those who may engage in other illegal political acts such as graffiti, destruction/vandalisation, attacking political leaders and opponents, are also considered as political participants since their actions may have effects on the politics and the political system.

\section{Bases of Political Participation}

Participation is the basis upon which every political system is built and takes place at several levels, such as running for elective offices, contributing money to party and candidates, 
working on campaigns, voting, are among others (Hess, Markson, \& Stein, 1988:347). Citizens participate in politics directly or indirectly. They also influence state policies, actions, programmes and politicians behaviours, apart from making choice of leadership and the process. They use both the easiest and cheapest means to participate in politics (Bakker \& Vreese, 2011; Thun, 2014; Lahabou \& Wok, 2011). However, traditional participation in politics is generally declining globally, especially with the use and proliferation of online and social media facilities (Milner, 2011), while the other aspect of protests and or demonstrations are now more associated with the young political participants (Dalton, 2011). In most developing democracies, political participation is perfunctory and mostly done out of either fear or for opportunism, rather than the real feelings of belonging and as a civic obligation (Kamrava, 2000:146). There is thus, a general and alarming decrease in public participation politics, particularly in the developing states (Skoric \& Poor, 2013).

It has therefore, been identified that the pyramid political participation comprises of activists, participants, onlookers, and the apolitical, who are at the bottom of the pyramid doing nothing and participating in nothing. Similarly, political parties, interest groups and public policies formulation/implementation are some of the key tools of political participation, but many Nigerians have now developed the political apathy habit (feeling detest, dejection and not interested in politics and political events and non-participatory attitude) or poor participation, which distances them from politics and the system. According to Jega (2007:22), for a long period in Nigeria's history, it has remained a disappointment to Nigerians that, politics democracy and its search, have remained elusive, despite the energy, resources and numerous trials, and not only in terms of participation, but the entire experiment with the politics and democracy. Apart from the apathy where Nigerians tend to participate, both the citizens and the politicians are mostly interested in manipulating the system to achieve selfish interests in what Rodee (1980) described as a 'machine' intended to be a vote catching device to facilitate access to power and state resources. Politics in the ordinary Nigerian context is an act of manipulation, deceit, and graft giving or taking among others. Similarly, the understanding and participation in Nigerian politics in the pre and post-colonial Nigerian is filled with hopes and expectations, but met with disappointments. Political parties, interest groups and public policies formulation or implementation are some of the key tools of the participation, and the greater the investments in social/state systems, the more likely the people are to participate and make impact in politics (Hess, et al., 1998). In Nigeria however, all the above and others have been marred, especially by the politicians, political parties and the state leadership. This results in poor participation and apathy. Over the period, Nigerians have developed political apathy and this has affected the entire political system, thereby raising more questions than answers as to the reasons for the poor participation or apathy.

It is clearly observered that there are conventional/normal participation - voting, engaging in election campaign, party membership, political meetings with the leadership, writing letters and participating in group actions; and unconventional participation - terrorism, sit-ins, boycotts and strikes, protest, demonstrations, writing complaints, petitions, and or protest 
letters among others (Irish et al., 1977:134; Chan, 2015); and unconventional/uncommon modes of political participation. As such, the bases for political participation in Nigeria include: political party; community (similar race, language, and ethnicity); neighbourhood (residence/geographical proximity); class (similar status, income, occupation); faction (united individuals) (Adapted from Flores \& Nooruddin, 2016; Irish et al., 1977:134).

\section{Voluntary Form of Political Participation}

There are voluntary forms of participation which is characterized by citizens' willingness to engage in: aspiration for an elective office; funding political party activities; campaigning; following up on issues; participating in party rallies and symposiums; establishing a political party/group; voting; and demonstration (Adapted from Irish et al., 1977:134; Chan, (2015).

\section{Push/Pull Factors of Political Participation in Nigeria}

There are a number of factors responsible for the push/pull participation in Nigerian politics. The factors, however, vary with time, environment and circumstances, but are sometimes intertwined with one another. Hence, there are unique and multi-causal factors that affect the participation in Nigeria.

\section{The Pull Factors to Political Participation in Nigeria}

The pull factors that entices political participation in Nigeria include: access to power; monetary benefits; regionalism; ethno-religious sentiments; socio-societal influence; relative political stability; extent of state/leadership commitment; family social status/ prestige; access to elites; average/high standard of living; geographical location; need for change; selfish interests; desire to maintain status quo; relative inclusiveness; roles of the social media; and popularity/legitimacy of state policies and programmes (Adapted from Kamrava, 2000; Skoric \& Poor, 2013; Jacob \& Abdullahi, 2007).

\section{The Push Factors of Political Participation in Nigeria}

The push factors from participation in Nigerian politics include: autocratic nature of parties; political instability; electoral malpractice; elites manipulation; misconception of politics; socio-societal inequality; poverty; poor governance; poor level of political socialization; long term effects of military rule; poor civic education; monetization of politics (Adapted from Waller, 2013; Tan \& Lee, 2013; Obasanjo \& Mabogunje, 1992; Jega, 2007; Fagge, 2002). 


\section{Political Parties}

Political parties are an important element of democracy and scholars have sought to understand the reason, how individuals join political parties, and what they would gain by doing so (Haute \& Gauja, 2015:1). In Nigeria, political parties, their characters, nature of formation, localisation and symbols, as well as the leadership structures are a major pull/push factor. Although ethno-regional politics is constitutionally prohibited in Nigeria (Mohammed, Aisha \& Saidu, 2018:464; Sections 221-225 of the Constitution of the Federal republic of Nigeria, 1999), its practice during the pre, early post-independence and recent politics have continued to influence the Nigerian politics, many Nigerians are pulled to participate, based on geo-regional, ethno-religious basis and orientation of political parties as may be covertly symbolised by their nature of establishment and leadership characters. This participation and roles of individuals as party members cannot be over-emphasised in a civilian or democratic setting as they provide legitimacy, organisation, labour and monetary resources, linkages, and education (Haute \& Gauja, 2015:2; Niemi, Weisberg \& Kimball, 2011:23; Katz, 1990). This is despite the fact that Nigerian political parties lack any unique, definite and clear content ideologies, manifestoes and programmes (Braji, 2014a:73 \& 83; Braji, 2014b:103; Adebayo, 2000:78; Othman, 1984; Oji, 1982:148).

\section{Political Socialisation, Culture, Ideology and Orientation}

Political socialisation, culture, ideology, orientation and enlightenment also determine political participation (Rosenstone \& Hansen, 2003:74 \& 135). Political socialisation, which according to Hess, Markson and Stein (1998:350), refers to the influences and experiences that enable citizens to define their political orientation as either conservative or liberal. This is very essential to every state and political system. Nigerians generally lack sound political socialisation and culture with major factors responsible such as ethnic differences, historical development, socio-economic structures, traditions, motives, emotions, symbols and norms of a people (Almond \& Verba, 1965; Ball, 1979).

On the other hand, political culture is "the bond between politics and society, the medium through which the two interact and interconnect" (Kamrava, 2000:146), and it is influenced by the feeling of national identity. To that effect, Finer (1962) broadly identifies four levels of political culture as: mature, low, minimal and developed, adding that a nation can only have a mature political culture if it has an approved process of power transformation, public recognition of sovereign authority and politically conscious citizens. In reality, these are very low and poorly observed in Nigeria. This is largely due to the lack of a comprehensive and nationally oriented political culture. As such, there are disappointments in political expectations, which often result in dissatisfied and negative political attitudes that in turn negatively affect the political culture and the system performance in Nigeria.Furthermore, political orientation is also defined by Kamrava (2000:127) as "those collective sentiments that govern the public's general outlook towards politics as a field of practice, as an abstract 
science and as a general guideline for the attainment of community or national power". Therefore, the absence or a lack of clear or vague political ideology and orientation; denial of internal democracy within Nigerian political parties and system influence the negative trend, results in poor participation and apathy in Nigerian politics. This is directly connected to the incoherent nature of Nigerian political parties characterized by vague constitutions, copy and paste manifestoes, incredible candidates, weak party machineries and near or absence of internal and external democratic principles within and among the parties (Braji, 2014b:73, 83; Braji, 2014b:103). Additionally, political and regime orientations are greatly determined and affected by the citizens' feelings and extent of national identity, and there exists a significant connectivity between national identity defined as "the way in which we view our national-self-worth and is the measure of pride in one's nationality", and political and regime orientations, as both are often inseparable and re-enforce one another (Kamrava, 2000:134 \&142-143).

\section{Political Marketing/Entrepreneurship}

Political marketing, the demands and supplies are now global and all the stakeholders such as governments, politicians the masses, and the media adopt the tools and forces of the market and marketing in order to design and sell products for patronage and satisfaction of the political consumers (Ormrad, Henneberg, O'Shaughnessy, 2013:9; Wymer \& LessMarshment, 2005:1). However, there are numerous manipulations, challenges and intricacies in the market, sale and consumption of the political products (parties, candidates, policies) as may be determined by the market (political arena/state), consumers (the citizens/public/ participants), and the marketers/suppliers - media professionals, political entrepreneurs, politicians and government (Mohammed \& Aisha, 2018).

Nigerian politicians, authorities and the citizens have embraced the global trend of political marketing in which parties, candidates, policies and programmes are marketed to the citizens, especially the potential voters. This is performed by both professionals and political, ethno-religious, regional and even conflict entrepreneurs, who are also engaged in not only marketing the parties, candidates and policies, but at the same time spread negative vices such as hate among the citizens based on religion, ethnicity, region and other vulnerabilities (Mohammed \& Aisha, 2018). These marketers and entrepreneurs do exercise immense influence on the push/pull to participation in Nigerian politics through marketing, display and promotion of their respective candidates, policies, and parties.

\section{Mistrust on the Politics, Politicians and the State System}

All over the world, and at different political levels, there is a decline in trust and lack of confidence from the United States nuclear deceptions, involvement in the Middle East affairs (El Baradai, 2011), to the EU-Brexit, the promised changes in Nigeria during the 
2015 general elections, and among others. There is a declining saga of political participation and trust in political leaders as citizens develop less interest and concern to politics largely because not only do governments fail to make genuine promises and fulfill their obligations, but that the older generations have not lived up to the citizens' expected role in governance (Mohammed \& Aisha, 2018). It is observed by Boyett (2008:1) that the world has become so complex, more connected, but 'unpredictable' and largely 'out of control', when unlike in the past, people no longer trust their leaders. Thus, the decline in both trust and participation in both local and international politics as there is a great relationship between an active governance and citizens' participation in the politics (Kidd, 2011:90). Boyett (2008:3) advocated how citizens' fall sick of politicians' promises and failures, corruption and consequently tired of voting as those voted put their interests ahead of the public.

Due to practical and bitter experiences, Nigerians do not actively participate, as they lack enthusiasm for they no longer trust politicians and have lost confidence in the state as Pious (1986:153-7) observed. The inability to trust politicians, dissatisfaction/disagreement with policies, lack of enthusiasm for candidates, cynics of voting, and loss of efficacy are some of the factors leading to apathy. With the disappointments in the political actors, the end result is what Kamrava (2000:134) referred to as "interpersonal distrust, and skeptism, the perception of politics as a controlled and cruel game played by giants at the expense of the masses...."

\section{Negative interpretation and Manipulation of the Politics}

Politics is originally a virtuous game and affair, but most people around the world have employed negative and unvirtuous practices such as deceit, manipulations and corruption into it such that in instances, politics, political system and the politicians are regarded, especially by the common citizens as dirty, devilish and devils characterised by theft, cabalism, deceit, manipulation, corruption, lies, ungodliness, immorality, and which and who must be deserted by every responsible and well-meaning person. Hence, Pious (1986:153) observed that people who believed negatively about politics, as a system of rigging and corruption, and benefitting some others at their expense, may decide that (politics) is no longer legitimate, ethical. and become apathetic; as the politicians are generally regarded as corrupt, incompetent and evil. The citizens' perception and understanding of politics is, greatly influenced and determined by the prevailing political institutions, practices and overall performance of the political/state leadership (Kamrava, 2000:134). Sequel to that, the character of Nigerian politics is one that portrays a high level of both passiveness and cynism towards the political offices holders.

\section{The Elites and Patron- Client Politics and Manipulation}

Societies are divided into two classes. The elites (rulers), who are a few in number, monopolise and enjoy power, control and direct things; and the 'ruled' who are numerous 
and controlled and directed by the few elites in a more or less legal way (Mosca, 1939:50; Peters, 2005:40-41). The elites shape the public/political and economic policies and affairs through the use and manipulation of religion, ethnicity, and politics among others (Levi \& Stoker 2000; Ball \& Peters, 2005; Hetherington, 1998). Foundational to this, patronclientelism exists in all politics, however, the extent, form and content and objectives vary, and are dependent upon on the levels of political development and socialization among others (Nicolas van de Walle in Kitschelt \& Wilkinson, 2007:50-67; Brun \& Diamond, 2014:1-14). The Elites/patron-client politics and relations also pull and push citizens to and from the Nigerian politics with massive deployment of influence, power, resources and manipulation of public policies for personal ends, rewards and patronage-clientelism.

Nigerian politics and political culture are built, and centred on patron-clientelism relations in which those in power or exercising influence on the status quo do any and everything to maintain their access, holding onto, and consolidation of economic and political powers through deliberate and calculated establishment of a pyramidal set-up of loyalists (Draper \& Ramsay, 2008:256). Thus, political clientelism, which is a patron-client political relationship characterised by highly personalized characters, is most often found in developing states. It also involves persons of un-equal status, wealth and prestige with client providing political support, mobilising voters, party back-up among others. The patron provides government jobs, contracts, loans, access to education and other state resources in exchange (Lemarchand, 1988:153-155). This patron-clientelism cuts across the Nigerian elites from the classes of both the politicians and the military, especially the retired generals who have successfully built a military industrial complex that holds Nigeria to ransom, with sponsorship of candidates, funding campaigns, establishing political parties, managing and manipulating transition to politics, remote and immediate powers on constitutions making and re-makings, orchestration of conflicts and violence. (Mohammed \& Aisha, 2018; Mohammed, et. al., 2018).

\section{Excessive Use of Money and other Material Inducements}

Individuals' resource disposal such as income, transportation, time, and energy determine political participation in a state (Rosenstone \& Hansen, 2003:133). Thus, the roles of money in politics is significant as Redish (2001:1) observes that "money talks", i.e., individuals, groups, parties with economic power, enjoy unjustified influence, and the imperativeness of "limiting the use of economic power for purposes of expression; and controlling the expression of the economically powerful". For the political parties and groups, the costs for capital and maintenance have dramatically increased and extravagant amount of finances and other resources are committed to organisations, administrations, campaigns elections, sponsoring candidates, among others. This has resulted in an increased usage of money in politics by both the state and political parties (Gunlicks, 1993:5; Shehu, Othman \& Osman, 2017). Hence, it has led to a shift from the traditional source of income to the parties, politicians, citizens, as well as the wealthy individuals, powerful interest groups and private organisations. This has also resulted in not only prominence, but also the dominance of 
money in the politics of states, especially the poor/developing democracies, but with more often negative consequences on the political system.

Additionally, Diclerico (2000:45) identified the main threats of money in politics as "it exerts an undue influence over access to electoral process; the election outcomes; and decisions on public policy". Although in any state/system, developed or developing, politics cannot be carried out without money, Nigeria's politics is excessively monetised (Sule, Sani \& Mat, 2017; Shehu, et al., 2017; Casas-Zamora \& Zovato, 2016:11; Fagge, 2002:82-90). Politics in Nigeria has become a purely monetary/materialistic affair with over-emphasis on monetisation of every aspect. This leads to the primacy of materialism over the rules, virtues and good ends, credibility and national interest. These altogether make both the politics and the Nigerian state affairs plutocratic, and a cash and carry state of hocks citizens (Obasanjo \& Mabagunjo, 1992:5-7 \& Jacob \& Abdullahi, 2007:65). Furthermore, Amadi (1982:89) stated that politics in Nigeria has become such a bad game that citizens as voters' must be materially bribed, while the politicians/parties are familiar with and notable for distribution of money and other materialistic valuables during election. Upon winning they would use all corrupt means to recover the invested resources during campaigns and elections. Such has been both a pulling for some and a pushing factor for many others, thereby making the polity corrupt, complex and consequent poor political participation and bad governance (Orewa, 1997).

\section{Socio-Economic Status}

Economy plays a significant and an indispensable role in determining the citizens' participation in politics and so individual's resource disposal such as income, transportation, time, and energy determine political participation (Kidd, 2011:64; Rosenstone \& Hansen, 2003:132-34). Apathy, poor and or optimum participation are thus, closely linked to economic condition/status. People need to attain basic necessities before having the psychology of political thinking, consciousness and rationality to exercise civic rights and obligations. This will equip them with the ability to claim their rights, meaningfully participate and make an impact. The majority of Nigerians are poor and unemployed. This has made them vulnerable towards negative activities such as thuggery, sale of votes, political bootlicking, cynism, and money politicking whilst others become politically apathetic having being preoccupied in struggles for survival first. In addition to that, politicians deliberately inject poverty into the society so as to easily woo the people into their camps with little resources they could offer, which monetises the entire politics.

Mass poverty as noted by (Mohammed et al. 2018) tends to generate citizens' general loss of confidence in state authorities with disrespect, ineffective government policies, general political apathy and social disillusion. Similarly, citizens with low status/class participate less in politics than those with higher class or status (Irish, Prothro, Markson \& Stein, 1977:107). Furthermore, Milbrath Lester (as cited in Irish et al. 1977:135) asserts that 
citizens who are close to the state authorities and politicians are more participatory and recognised with the politics because of higher rate of social interaction and increased rate of participation with many stimulis.

\section{Political Instability and Electoral Malpractice and Violence}

Political participation is affected by what is referred to as 'violent votes', which denotes that many of the elections end with violence. Therefore, legitimacy and success of every regime, and democracy largely depends on the credibility, effectiveness, efficiency and popularity of its electoral system (Shehu et al., 2017; Flores \& Nooruddin, 2016:144). Throughout the political history of Nigeria, all the civilian democratic regimes have been associated with electoral malpractices and crises, which in most cases undermines the legitimacy, performance of the regimes, and the Nigerian state security system. Obasanjo and Mabagunjo (1992:5-7) have noted that the Nigerian electoral character is the communal orientation of Nigerians, who hardly consider themselves as national entity which makes it difficult to ignite patriotisme. In Nigeria, electoral victory is a do or die affair and an electoral defeat is regarded as a loss of everything. Both the ruling party's and the opposition hardly accept unfavourable results or tolerate oppositions; the ultimate goal is to participate/ engage in politics to win elections in all circumstances. (Sule, Sani \& Mat, 2017; Shehu, et. al., 2017). Furthermore, this will result in capturing and holding on to power, and accessing state resources for personal, family and particularistic ends. Electoral malpractice and crises have been characteristic of all the elections, though at varying levels and contexts. Many citizens abhor both the malpractice and attendant crises and eventually pull out, while the other beneficiaries, are pushed to carry out the same malpractice, orchestrate the crisis, or at best to attempt at cleaning the system.

\section{Gender, Religion, Ethnicity}

Issues of gender, religion, ethnicity and language determine and affect political participation (Rosenstone \& Hansen, 2003:77). Due to heterogeneities of the Nigerian state, political participation is affected by gender, especially in terms of full participation with respect to the female sex. Believed to be a weaker sex in many cultures and religions, the female participation in Nigerian politics is regulated by religion, especially Islam, which divinely regulates the degree of female participation in public affairs and spaces, and various cultural and socio-structural provisions. The female in most settings are regarded as a weak and inferior sex, thus limiting their socio-political, economic and other opportunities which hinders their zeal to break the glass ceiling (Kreitner \& Knicki, 2001). The matrix and interplay of ethnicity and religion are also manipulated by the elites and ethno-religious entrepreneurs who influences the push/pull factors of the citizens' participation in the Nigerian politics. 


\section{Levels of Political Participation}

Participation in politics are varied levels and degrees, and those are largely determined by political socialization, culture and orientation. Irish et al. (1977:134) gave a vivid hierarchy of political participation comprising of the gladiatorial, transitional, spectator stages and activities, while at the bottom of the participation are the apathetic, who do nothing more than talk about politics. Meanwhile, the nominees who have succeeded, are in the midst of: holding public and party office; being a candidate for office; soliciting political funds; attending a caucus or a political party functions; contributing time in a political campaign; attending political meeting or rally; making a monetary contribution to a party or a candidate; contacting an official or a political campaign; wearing a button or putting a sticker on the car; attempting to talk to another into voting a certain way; initiating a political discussion; voting; talking about politics; and the last as apathetic (Irish et al., 1977:134). These levels/ activities also include violence intended to support or go against a candidate, policy, and the state system as acts and forms of political participation.

The levels of participation include: contacting party officials; talking about politics; voting; initiating/participating in political discussions; talking to others to influence them politically; wearing dresses, putting stickers, putting badges and other party symbols; holding any party/ public office; making donation to a certain party; attending political rallies; contributing to political campaigns; attending party meetings; sourcing political funds; and contesting for an office (Adapted from Irish et. al., 1977:134; Kamrava 2000; Waller, 2013; Tan \& Lee, 2013; Jacob \& Abdullahi, (2007).

Political participation now comprises of wide range of actions and reactions such as participation sympathising, supporting protests and social media postings, writing/signing public petitions/complaints; challenging politicians/leaders on public matters and actions; voting and other electoral matters; membership of politically groups, organizations and institutions, among others (Waller, 2013; Tan \& Lee, 2013).

\section{Politics, Participation and Apathy}

Political participation and apathy fluctuate, because the politics itself, is determined and influenced by a number of factors that include: level of political awareness and socialization, social status in society, standard of living/level of well-being, environmental and social influences, the extent of observing and guaranteeing the principles of rule of law (Shehu, Othman and Osman, 2016), and socio-cultural which includes religious and gender factors. Each of the above, influences participation or apathy relative to the environment and societal/state's establishments and settings. In practice, individuals with open and better state systems, especially the more democratic are likely to have more participants in politics due to inclusion and openness by the state and political operators. Individuals with relatively stable standard of living are more likely to participate, act/react to political events, process and issues, as they are to some degree less economically constrained. This implies that 
poverty undermines the level of political participation and more linked to poor participation and apathy as the citizens concentrate and spend more time in search of the basic needs and satisfaction of same.

Moreover, Huntington (1968:78) has observed that those who have high socio-economic status participated more in politics than those with lower socio-economic status. This indicated that political participation has a direct link to socio-economic well-being; and mass poverty tends to generate citizens' general loss of confidence in state authorities with disrespect, ineffective government policies, general political apathy and social disillusion among citizens (Mohammed et al, 2018). The level of education also determines participation in politics as educated citizens who can read, write, understand and analyse issues, are more likely to participate. However, the uneducated ones, may not understand or analyse issues and situations; attitude of government in states like Nigeria. This is also a determining factor for where the citizens have respect, confidence and are interested in government are more likely to participate as against irresponsible and unpopular, autocratic governments. Political participation increases awareness, check, transparency, responsibility, and inclusion, and improves political culture and socialization, which all lead to increased political participation.

In view of the above findings, there is very significant relationship between civic education, participation in politics, build of trust and legitimacy of a political system and regime in Nigeria. Fulfillment of promises /meeting up with state and political responsibilities, increase levels of trust and participation in politics. Whence, political trust is built, participation, stability, progress and development are achieved more. However, the overall effects of poor political participation/apathy include: alienation and distance between the citizens and the politics/leadership as well as the state system; absence of or poor check on the state and the system; loose and an irresponsible political system; breed of irresponsible political/leadership/regime and entrenchment of poor political culture and orientation. These will result in the ultimate collapse of constitutionalism, and degeneration of political socialisation, culture, national integrity and orientation.

\section{Conclusion and Summary}

In conclusion, political and state systems can neither be sustained, nor would they thrive without the citizens' participation and, contributions in either conventional or unconventional ways. Political participation in Nigeria, together with the Nigerian socio-political and economic development remained unstable, uncertain and poor on one hand, and then rising on the other due to several factors. The identified push/pull factors have affected the politics and system in both positive and negative ways. The negative effects of push factors are due to manipulation of ethnicity and religions, patron-clients relations at all levels of politicking, prebendal politics, the politicians intent to win elections at all costs/deployment of illegal 
and unpopular means of acquisition and usage of political powers, failure to meet up with political/state obligations (Sule, et. al., 2017); excessive use of money in the political activities and processes; absence of clearly defined political parties' ideologies; ever declining trust between citizens and elites, including the politicians/political system. These have altogether inflicted negative consequences on the Nigerian political/state system, and a decline of both extent and level of the citizens' political participation. Most Nigerians have become disenchanted with the politics, politicians and the Nigerian state system itself, largely on the accounts of the system and politicians' attitudes. Therefore, the trend reflects unpopularity of the state system as well as disaffection with the attitudes of the politicians, and the political parties.

\section{References}

Adebayo, A., (2000). Principles and practice of public administration in Nigeria. Ibadan: Spectrum Books.

Almond, G., \& Verba, S., (1965). The civic culture. Boston: Little Brown and Company. Ball, A. R. (1970). Modern politics and government. London: The Macmillan Press.

Bakker, T. P., \& Vreese, C. H. (2011). Good news for the future? Young people, internet use, and political participation. Communication Research, 38(4), 451-470.

Ball, A. R., (1979). Modern politics and government. London: The Macmillan Press.

Ball, A. R., \& Peters, B. G. (2005). Modern politics and government. New York, NY: Palgrave Macmillan.

Boyett, J. H., (2008). Won't get fooled again: A voter's guide to seeing through the lies, getting past the propaganda, and choosing the best leaders. New York, NY: American Management Association (AMACOM).

Braji, I. (2014a). The Nigerian state: From democracy to kakistocracy. Ibadan: University Press.

Braji, I. (2014b). The Nigerian military: Origins, politics and capital accumulation. Ibadan: University Press.

Brun, D. A., \& Diamond, L. (Eds.). (2014). Clientelism, social policy, and the quality of democracy. Maryland: John Hopkins University Press.

Carpini, M. X. D. (2000). Gen. com: Youth, civic engagement, and the new information environment. Political Communication, 17(4), 341-349.

Chan, S. (2015). New media and political participation of Cambodian youth. University of Porto.

Casas-Zamora, K., \& Zovatto, D. (2016). The cost of democracy: Essays on political finance in Latin America. Stockholm: International Institute for Democracy and Electoral Assistance (IDEA).

Constitution of the Federal Republic of Nigeria. (1999). Lagos: Government Printer.

Curran, J., Fenton, N., \& Freedman, D. (2012). Misunderstanding the internet. New York, NY: Routledge.

Dalton, R. J. (2011). Introduction. The debates over youth participation. Engaging youth in politics: Debating democracy's future. New York and Amsterdam: International Debate Education Association, 1-15. 
Diclerico, R. E. (2000). Political parties, campaigns and elections. New Jersey, NJ: Prentice Hall.

Draper, A., \& Ramsay, A. (2008). The good society. New York, NY: Pearson Education Books.

Education, audio-visual and culture executive agency (EACEA). (2013). Youth in action - beneficiaries space. Retrieved from https://eacea.ec.europa.eu/sites/2007-2013/ archiving.

El Baradai, M. (2011). The age of deception: Nuclear diplomacy in treacherous times. New York: Picador.

Fagge, K. S. (2002). Democracy in Nigeria's fourth republic: Myth, realities, challenges and prospects. Kano: Triumph Publishers.

Finer, S. E. (1962). The man on horseback: The role of military in politics. London. Pall Mall Press.

Flores, T. E., \& Nooruddin, I. (2016). Elections in hard times: Building stronger democracies in the $21^{\text {st }}$ century. Cambridge: Cambridge University Press.

Gromping, M. (2014). Echo Chambers: Partisan facebook groups during the 2014 Thai election. Asia Pacific Media Educator, 24(1), 39-59.

Gunlicks, A. B. (Ed.). (1993). Campaign and party finance in North America and Western Europe. Boulder, Colorado: Westview.

Harris, A., Wyn, J., \& Younes, S. (2010). Beyond apathetic or activist youth. Young, 18, 9-32.

Haute, E. V., \& Gauja, A. (Eds.). (2015). Party members and activists. Oxon, London: Routledge Francis Taylor.

Hetherington, M. J. (1998). The political relevance of political trust. American Political Science Review, 92(4), 791-808.

Hess, B. B., Markson, E. W., \& Stein, P. (1988). Sociology. New York: Macmillan Publishing Company.

Huntington, S. P. (1968). Political order in changing societies. New Haven: Yale University Press.

Irish, D. M., Prothro, J. W., \& Richardson, R. J. (1977). The politics of American democracy. New Jersey: Prentice Hall.

Jacob, J., \& Abdullahi, A. (2007). The legislature, economic reforms and democracy in Nigeria: An assessment. Journal of Legislative Studies, 1(1). Center for Legislative studies.

Jega, A. M. (2007). Democracy, good governance and development in Nigeria. Ibadan: Spectrum Books.

Kahne, J., \& Westheimer, J. (2006). The limits of political efficacy: Educating citizens for a democratic society. Political Science \& Politics, 39(2), 289-296.

Kamrava, M. (2000). Politics of society in the developing world. London: Routledge Taylor and Francis Group.

Katz, R. S. (1990). Party as linkage: A vestigial function? European Journal of Political Research, 18(1), 143-161.

Kidd, Q. (2011). Civic participation in America. New York, NY: Palgrave Macmillan.

Kreitner, R., \& Kinicki, A. (2001). Organisational behaviour. New York, NY: Irwin/ McGraw- Hill. 
Lahabou, W. (2011). Relationship between facebook usage and youth political participation: A Sub-Saharan African context. Kulliyah of Islamic Revealed Knowledge and Human Sciences, 1-10.

Levi, M., \& Stoker, L. (2000). Political trust and trustworthiness. Annual Review of Political Science, 3(1), 475-507.

Lemarchand, R., (1988). The state, the parallel economy and the changing structure of patronage systems. In Donald R., \& N. Chazan (Eds.), The precarious balance: the state and society in Africa. Boulder: Westview Press.

Macedo, S., et al. (2005). Democracy at risk: How political choices undermine citizen participation, and what we can do about it. Washington, DC: Brookings.

Mayoral, J. (2011). Democratic improvements in the European Union under the Lis bon treaty, institutional changes regarding democratic government in EU. European University Institute. Robert Shuman Centre for Advanced Studies.

McManimon, S. J. (2014). Political engagement and the shifting paradigm from traditional to social media. Indiana: University of Pennsylvania.

Milner, H. (2011). Political dropouts and the internet generation. In Dunkels, E. G. M., Franberg, \& C. Hallgren (Eds.), Interactive media use and youth: Learning knowledge exchange and behavior (p. 186-206).

Mohammed, I. S., \& Aisha, A. A. (2017). Fulani/herdsmen-farmers conflict in Nigeria: Emerging dimensions, complications and the theatre. Beau Bassin, Mauritius: Lambert Academic Publishing.

Mohammed, I. S., Aisha, A. A., \& Saidu, A. (2018). Nigerian political development. Beau Bassin, Mauritius: Lambert Academic Publishing.

Mosca, G. (1939). The ruling class. New York, NY: McGraw-Hill.

Neimi, R. G., Weisberg, H. F. \& Kimball, D. C. (Eds.). (2011). Controversies in voting behavior. Washington, DC: CQ Press.

Obasanjo, O. \& Mabogunje, A. (Eds.). (1992). Elements of democracy. Abeokuta: Africa Leadership Forum.

Oji, M. K. (1982). The Nigerian ethical revolution: 1981-2000 AD. Enugu: Mazi Kanu Oji. Orewa, O. G. (1997). We are all guilty: The Nigerian crisis. Ibadan: Spectrum Books.

Ormrad, R. P., Hennerberg, S. C., \& O’Shaughnessy, N. J. (2013). Political marketing: Theory and concepts. London: Sage Publications.

Othman, S. (1984). Classes, crisis and coup. The demise of Shagari's regime. African Affairs, 83, (333), 441-461.

Pious, R. M. (1986). American politics and government. New York: McGraw-Hill Company. Preston, P. W. (1997). Political/cultural identity: Citizens and nations in a global era. London: Sage Publications.

Redish, M. H. (2001). Money talks: Speech, economic power, and the values of democracy. New York, NY: New York University Press.

Rodee, C. C. (1980). Introduction to political science. London: Oxford University Press.

Rosenstone, S. J., \& Hansen, M. (2003). Mobilisation, participation, and democracy in America. New York, NY: Pearson Education. 
Skoric, M. M., \& Poor, N. (2013). Youth engagement in Singapore: The interplay of traditional and social media. Journal of Broadcasting and Electronic Media, 57(2), 187-204.

Shehu, I. M., Othman, M. F., \& Osman, N. B. (2017). Nigeria's politics of electoral reforms: In whose interest? Asian Journal of Multidisciplinary Studies, 5(5), 25-32.

Shehu, I. M., Osman, N., \& Othman, M. F. (2016). Nigerian citizens and fundamental rights: Myth, manoeuvre and reality. Journal of International Studies (JIS), 12, 5364.

Sule, B., Sani, A. M., \& Mat, B. (2017). Independent National Electoral Commission and campaign financing monitoring in Nigeria: The 2015 general elections. Journal of International Studies (JIS), 13, 15-31.

Stolle, D., \& Hooghe, M. (2011). Shifting inequalities: Patterns of exclusion and inclusion in emerging forms of political participation. European Societies, 13(1), 119-142.

Suhana, S., \& Ali, S. (2012). Values and attitudes in political participation: Case study in Hulu Langat District, Malaysia. $2^{\text {nd }}$ Annual International Conference on Political Science, Sociology and International Relations, (Pssir).

Tang, G., \& Lee, F. L. F. (2013). Facebook use and political participation: The impact of exposure to shared political information, connections with public political actors, and network structural heterogeneity. Social Science Computer Review, 31(6), 763-773.

Thun, V. (2014). Youth political participation in Cambodia: Role of information and communication technologies (ICTs). Illinois: Northern Illinois University.

Walle, N. van de (2007). Meet the new boss, same as the old boss? The evolution of political clentelism in Africa. In Kischelt, H. \& I. S. Wilkinson (Eds.) Patrons, clients, and policies: Patterns of democratic accountability and political competition. Cambridge: University Press.

Waller, L. G. (2013). Enhancing political participation in Jamaica: The use of facebook to "cure" the problem of political talk among the Jamaican youth. SAGE Open, 3(2).

Wilson, G., (2018). Political party conflicts and democratic participation in Nigeria, 20032014. Nigerian Journal of Social Sciences, 10(1), 124-139. 